\title{
Three years on demography of a group of Alouatta guariba clamitans Cabrera (Primates, Atelidae): growth and fragmentation ${ }^{1}$
}

\author{
João M. D. Miranda 2, 3; Itiberê P. Bernardi 2; Rodrigo F. Moro-Rios ${ }^{2,3}$ \& Fernando C. Passos ${ }^{2}$ \\ ${ }^{1}$ Contribuition number 1647 of the Departamento de Zoologia, Universidade Federal do Paraná. \\ 2 Laboratório de Biodiversidade, Conservação e Ecologia de Animais Silvestres, Departamento de Zoologia, Universidade \\ Federal do Paraná. Caixa Postal 19020, 81531-980 Curitiba, Paraná, Brasil. E-mail: guaribajoao@yahoo.com.br, \\ monobernardi@yahoo.com.br, rtkd@pop.com.br,fpassos@ufpr.br \\ ${ }^{3}$ Bolsista do CNPq.
}

\begin{abstract}
This study was carried out in the Chácara Payquerê do Bugre, State of Paraná, Southern Brazil (25⒉ $22^{\prime \prime} \mathrm{S}$ and $49^{\circ} 39^{\prime} 24^{\prime \prime} \mathrm{W}$ ) and reports on the demography of a group of Alouatta guariba clamitans Cabrera, 1940 followed monthly during three years (from February, 2002 to March, 2005). The growth and subsequent fission of the group are described and argued, as well as their possible underlying causes, focusing on the population ecology and social behavior of this taxa.
\end{abstract}

KEY WORDS. Brown howlers; dispersal; group fission; group growth; population ecology.

RESUMO. Três anos sobre a demografia de um grupo de Alouatta guariba clamitans Cabrera (Primates, Atelidae): crescimento e fragmentação. Este estudo foi realizado na Chácara Payquerê do Bugre, Estado do

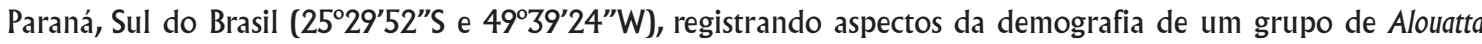
guariba clamitans Cabrera, 1940 acompanhado mensalmente durante três anos (de fevereiro de 2002 a março de 2005). O crescimento e a subseqüente fissão do grupo são descritos e discutidos, bem como suas possíveis causas, enfocando a ecologia populacional e o comportamento social deste taxa.

PALAVRAS-CHAVE. Bugio-ruivo; crescimento grupal; dispersão; ecologia populacional; fissão de grupo.

Howler monkeys (genus Alouatta Lacépède, 1799) are social animals that form groups which usually harbor more adult females than adult males (Altmann 1959, Rudran 1979, Neville et al.1988, Rumiz 1990). The social structure of howler monkeys is intimately related to their demographic patterns (RUDRAN 1979, Rumiz 1990, Brockett et al. 2000, Miranda et al. 2004, Miranda \& PAssos 2005). The knowledge on the demographical variation of a taxon might lead to important insight into its behavioral ecology, and might represent an important tool for planning management strategies and species conservation (STRIER 1991). Studies on the demography or populational ecology of Brazilian primates are still uncommon (STRIER 1987, 1991, 1999, LyNCH \& Rímoli 2000, Dias \& Strier 2003, Miranda et al. 2004, Miranda \& Passos 2005). The brown howler monkeys (Alouatta guariba clamitans Cabrera, 1940) is a social animal that lives in relatively small groups (2-13 individuals - Neville et al. 1988, Treves 2001, Miranda \& Passos 2005). The fragmentation of howler monkey groups and their contexts are still poorly documented; however, it is believed that it ensues when group size exceed a stable average (Rudran 1979, Carrera-Sánchez et al. 2003, Miranda \& Passos 2005). In this study, data on the demography, growth and fragmentation of a group of brown howler monkeys is presented.

\section{MATERIAL AND METHODS}

This study was conducted in the Chácara Payquerê do Bugre (90ha), located in the Bugre District, Municipality of Balsa Nova, State of Paraná, southern Brazil $\left(25^{\circ} 29^{\prime} 52^{\prime \prime} S\right.$ and $\left.49^{\circ} 39^{\prime} 24^{\prime \prime} \mathrm{W}\right)$. The study area is a 700 ha remnant of Araucaria Pine Forest and is part of the conservation unit known as the Area for Environmental Protection of the Devonian Scarp. Elevation in this area varies between 935 and $1145 \mathrm{~m}$ above sea level. The climate is $C f b$ (temperate), according to the Köppen classification (IAPAR 1978). Annual average rainfall is around $1600 \mathrm{~mm}$, and annual average temperature is $18{ }^{\circ} \mathrm{C}$ (data obtained in the meteorological station of the Municipality of Lapa). The forest is formed by an association between Ocotea porosa (Ness.) L. Barroso Barr. (imbuia), Ilex paraguariensis St. Hil. (erva-mate), Podocarpus lambertii Klotz. (pinheiro bravo) and Araucaria angustifolia (pinheiro-do-paraná) (Bertol.) O. Kuntze (MaAcK 1968).

From February, 2002 to March, 2005, several studies on the ecology and behavior of $A$. g. clamitans have been carried out in the study area (Miranda \& Passos 2004, 2005, Miranda et al. 2004). The present study focused on a group of brown howler 
monkeys, recording monthly its sex/age composition, its demographic changes and its fragmentation during three years. Demographic data were obtained using the ad libitum method (Altmann 1974), reccording the changing of age categories, births and disappearances. Age/sex categories used in the present study were proposed by Mendes (1989): infant, juvenile I, juvenile II, subadult male, adult female and adult male. All animals were identified and recognized based on their age/ sex categories, body size, coloration and individual marks.

\section{RESULTS}

In February, 2002, the study group (G. Forninho) was composed by six individuals: two adult males (AM), three adult females (AF), and a juvenile I (JI). In 2003, four births were recorded: two in January (male and female), one in July (male), and one in August (male). In January, 2004 the dominant AM died or disappeared, apparently causing social instability (MIRANDA et al. 2004). A fragmentation into two groups ensued: G. Carrano and G. Vavá (Fig. 1). This fragmentation occurred gradually over a period of four months (January to April) and began with what seemed to be the formation of subgroups. Encounters between subgroups became increasingly sporadic, until the rare encounters between members of the newly formed groups included agonistic behaviors. The new configurations were: G. Vavá with two AFs, one SAM, one JII (male) and two JI; G. Carrano with one AM, one AF and one JII (female). After fragmentation, two births occurred in G. Vavá, one in April (male) and another in July (male), reaching a total of 8 individuals.

Starting in July, a change in the age class of the SAM into $\mathrm{AM}$ in the G. Vavá brought about a new fragmentation, also proceeding slow and gradually as before. This new fragmentation generated a group called G. Piá, which was composed by one AM, one AF, one JII, one JI and one infant (Fig. 1). In December, 2004, the JII male was observed wandering solitarily outside the home range of either of the original groups in four different occasions. When this individual attempted to approach a group, it was expelled by adult group members (both males and females).

\section{DISCUSSION}

A primate social group must have an appropriate size to maintain a stable formation (CARPENTER 1934, RUdRAN 1979, Dunbar 1988, CARRERA-SÁnchez et al. 2003). According to STrier et al. (1993), the development of subgroups might be the first step toward group fission. The fission of a group might be a natural consequence of its growth and development (SANTINI 1985). The growth of a group might be one of the determining factors in their fragmentation (SANTINI 1985, CARRERA-SÁnchez et al. 2003, Miranda \& Passos 2005). The first fission of a group might occur when the number of individuals is well above average (6.25 individuals/group, according to the review for this species by Miranda \& Passos 2005). This fact, associated with the social destabilization caused by the loss of a dominant male, might have caused the rupture of the G. Forninho, splitting it into two groups (G. Vavá and G. Carrano). Apparently, the adult male was expelled by a female, possibly to protect her infant against infanticide (see Miranda et al. 2004, Aguiar et al. 2005).

The second fragmentation might have simply resulted from weak associations, increasing the probability of group fission according to CARPENTER (1934). The formation of small groups in A. senilicus was also considered unstable by RuDran (1979). Alternatively, the second fragmentation might have been caused by the presence of a majority of juvenile males in the group. Subadult females integrate themselves as adult females into their own groups, or they can simply migrate (RUDRAN 1979, BONVICINO 1989, Calegaro-Marques \& Bicca-Marques 1996, Miranda \& Passos 2005). The formation of a group with two adult males with age graded could generate instability merely by the presence of two adult males that would competing for copulation and group leadership (Mendes 1989, Calegaro-Marques \& Bicca-Marques 1997). Finally, the insertion (or insertion attempt) of a new male into a group might lead to aggressive behaviors and intolerance by adult individuals (RUDRAN 1979, FroEHLICK et al. 1981, Zunino et al. 1986, Mendes 1989, Zucker \& Clarke 1998). That is, in addition to group increase, the birth of more males than females might also increase the probability of group fragmentation. However, the death or disappearance of the adult dominant male is probably the most important event to generate subsequent fragmentation (Miranda et al. 2004).

\section{REFERENCES}

Aguiar, L.; G. Ludwig; L.S. Malanski; C.L.S. Hilst \& F.C. Passos. 2005. Tentativa de infanticídio por um macho dominante de Alouatta caraya (Humboldt) (Primates, Atelidae) em um infante extra-grupo devido a influência do observador. Revista Brasileira de Zoologia, Curitiba, 22 (4): 1201-1203.

Altmann, S.A. 1959. Field observations on a howling monkey society. Journal of Mammalogy, Lawrence, 40 (3): 317-330.

Altmann, J. 1974. Observational study of behavior: sampling methods. Behaviour, Leiden, 40: 227-267.

Bonvicino, C.R. 1989. Ecologia e comportamento de Alouatta belzebul (Primates: Cebidae) na Mata Atlântica. Revista Nordestina de Biologia, João Pessoa, 6 (2): 149-179.

BRocketT, R.C.; R.H. Horwich \& C.B. Jones. 2000. Female dispersal in the Belizean black howling monkey (Alouatta pigra). Neotropical Primates, Washington, 8 (1): 32-34.

Calegaro-Marques, C. \& J.C. Bicca-Marques. 1996. Emigration in a black howling monkey group. International Journal of Primatology, Chicago, 17 (2): 229-237.

Calegaro-Marques, C. \& J.C. Bicca-Marques. 1997. Comportamento agressivo em um grupo de bugios-pretos, Alouatta caraya (Primates, Cebidae), p. 29-38. In: S.F. Ferrari \& H. Schneider (Eds). A Primatologia no Brasil - 5. Belém, Sociedade Brasileira de Primatologia, Editora Universitária, UFPA, 364p.

Carpenter, C.R. 1934. A field study of the behavior and social relations of howling monkeys. Comparative Psychology

Revista Brasileira de Zoologia 23 (3): 703-706, setembro, 2006 


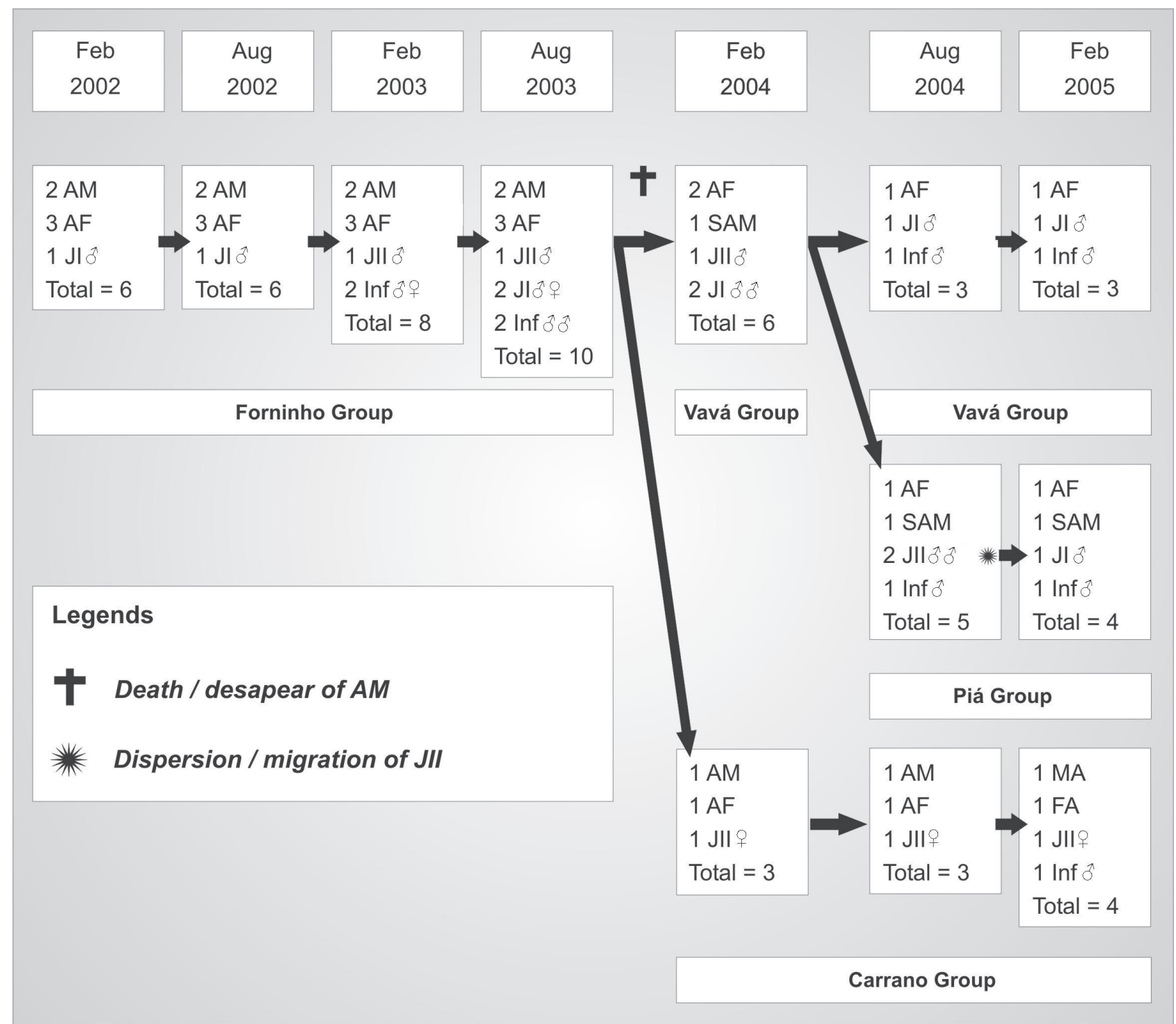

Figure 1. Schematic representation of the demographic characteristics of the G. Forninho, its growth and fragmentation.

Monographs, Baltimore, 10: 1-167.

Carrera-Sánchez E; G. Medel-Palacios \& E. Rodríguez-Luna. 2003. Estúdio poblacional de monos aulladores (Alouatta palliata mexicana) em la Isla Agaltepec, Veracruz, México. Neotropical Primates, Washington, 11 (3): 176-180.

Dias, L.G. \& K.B. Strier. 2003. Effects of group size on ranging patterns in Brachyteles arachnoides hypoxanthus. International Journal of Primatology, Chicago, 24 (2): 209-221.

Dunbar, R.I.M. 1988. Primate Social Systems. London, Croom Helm, 373p.

Forehlick, J.K.; R.W. Thorington Jr. \& J.S. Otis. 1981. The demography of howler monkeys (Alouatta palliata) on Barro Colorado Island, Panama. International Journal of
Primatology, Chicago, 2: 207-236.

IAPAR. 1978. Cartas climáticas básicas do Estado do Paraná. Instituto Agronômico do Paraná, Londrina, 38p.

LyNCH, J. W. \& J. Rímoli. 2000. Demography of a group of tufted capuchin monkeys (Cebus apella nigritus) at the Estação Biológica de Caratinga, Minas Gerais, Brazil. Neotropical Primates, Washington, 8 (1): 44-49.

MAACK, R. 1968. Geografia física do Estado do Paraná. Curitiba, Max Roesner, 350p.

Mendes, S.L. 1989. Estudo ecológico de Alouatta fusca (Primates: Cebidae) na Estação Biológica de Caratinga, MG. Revista Nordestina de Biologia, João Pessoa, 6 (2): 71-104.

Miranda, J.M.D. \& F.C. Passos. 2004. Hábito alimentar de Alouatta 
guariba (Humboldt, 1812) (Primates: Atelidae) em Floresta com Araucária, Paraná, Brasil. Revista Brasileira de Zoologia, Curitiba, 21 (4): 821-826.

Miranda, J.M.D. \& F.C. PAssos. 2005. Composição e dinâmica de grupos de Alouatta guariba clamitans Cabrera, 1940 (Primates, Atelidae) em Floresta Ombrófila Mista no Estado do Paraná, Brasil. Revista Brasileira de Zoologia, Curitiba, 22 (1): 99-106.

Miranda, J.M.D.; I.P. Bernardi; R.F. Moro-Rios; L.M. Aguiar; G. LudWIG \& F.C. PAssos. 2004. Social structure of Alouatta guariba clamitans: a group with a dominant female. Neotropical Primates, Washington, 12 (3): 135-138.

Neville, M.K.; K.E. Glander; F. Braza \& A.B. Rylands. 1988. The Howling Monkeys, Genus Alouatta, p. 349-453. In: R.A. Mittermeier; A.B. Rylands; A. Coimbra-Filho \& G.A.B. Fonseca (Eds). Ecology and behavior of Neotropical Primates. Washington, World Wildlife Fund, col. 2, 610p.

RUDRAN, R. 1979. The demography and social mobility of the red howler (Alouatta seniculus) population in Venezuela, p. 107126. In: J.F. EISENBERG (Ed.). Vertebrate ecology in the Northern Neotropics. Washington, Smithsonian Institution Press, 271p.

Rumiz, D.I. 1990. Alouatta caraya: Population density and demography in Northern Argentina. American Journal of Primatology, Calgary, 21: 279-294.

SAntini, M.E.L. 1985. Padrões de atividade diária de Alouatta caraya (Primates, Cebidae), reintrodução no Parque Nacio- nal de Brasília, p. 293-304. In: M.T. Mello. (Ed.). A Primatologia no Brasil - 2. Belo Horizonte, Sociedade Brasileira de Primatologia, 232p.

STRIER, K.B. 1987. Demographic patterns in one group of muriquis. Primate Conservation, Washington, 8: 73-74.

Strier, K.B. 1991. Demography and conservation of an endangered primate, Brachyteles arachnoides. Conservation Biology, Gainsville, 5 (2): 214-218.

Strier, K.B. 1999. Predicting primate responses to "stochastic" demographic events. Primates, Ichi, 40 (1): 131-142.

Strier, K.B.; F.D.C. Mendes; J. Rímoli; A.O. Rímoli. 1993. Demography and social structure of one group of muriquis (Brachyteles arachnoides). International Journal of Primatology, Chicago, 14 (4): 513-526.

Treves, A. 2001. Reproductive consequences of variation in the composition of howler monkey (Alouatta spp.) groups. Behavioral Ecology and Sociobiology, Heidelberg, 50 (1): 61-71.

Zucker, E.L. \& M.R. Clarke. 1998. Agonistic and affiliative relationships of adult female howlers (Alouatta palliata) in Costa Rica over a 4-year period. International Journal of Primatology, Chicago, 19 (3): 433-449.

Zunino, G.E.; S.C. Chalukian \& D.I. Rumiz. 1986. Infanticidio y desaparicion de infantes asociados al reemplazo de machos en grupos de Alouatta caraya, p. 185-190. In: M.T. Mello (Ed.). A Primatologia no Brasil - 2. Belo Horizonte, Sociedade Brasileira de Primatologia, 530p.

Received in 02.IX.2005; accepted in 17.VIII.2006. 